\title{
First Report of Ashy stem blight caused by Macrophomina phaseolina on Aeonium canariense in Egypt
}

\author{
Mokhtar M. Abdel-Kader*, Nehal S. El-Mougy, Mohamed D.E.H. Aly and Sirag M. Lashin
}

Department of Plant Pathology, National Research Centre, Dokki, 12622, Giza, Egypt

\begin{abstract}
Cactus plants Aeonium canariense L. (Webb \& Berthelot) showing symptoms of ashy stem blight disease, collected from some ornamental nurseries, resulted in isolation of the causal organism Macrophomina phaseolina (Tassi) Goid. The in vitro optimum temperature for fungal growth was recorded at $30^{\circ} \mathrm{C}$. Topsin-M showed high inhibitory effect on the fungal growth in vitro. Complete growth inhibition of $M$. phaseolina was observed at concentration of $4 \mathrm{ppm}$, while the growth of the bioagent Trichoderma harzianum inhibited completely at $10 \mathrm{ppm}$. Antagonistic ability of $T$. harzianum against $M$. phaseolina increased gradually in the presence of the fungicide in growth medium to cause complete reduction in pathogenic fungal growth at 2ppm of Topsin-M. Under greenhouse conditions application of integrated treatment of $T$. harzianum and Topsin-M had superior effect for suppressing the disease incidence of cactus plants Aeonium canariense $L$. by $100 \%$ comparing with each individual treatment of either fungicide (86.67\%) or the bioagent $(73.33 \%)$. It could be suggested that application of biological and fungicidal integrated treatment might be used as successful control measure for ashy stem blight of cactus plants Aeonium canariense $L$. cactus plants Aeonium canariense $L$. To the best of our knowledge this is the first report for M. phaseolina caused infection to cactus $A$. canariense in Egypt.
\end{abstract}

Keywords: Biological control, charcoal rot, Integrated control, Macrophomina phaseolina, Topsin-M, Trichoderma harzianum

\section{Introduction}

Ornamental plants had received a great attention in the last decades. They represent great commercial value because of their usage for gardens decoration in museum, hotels, touristic villages, private villas and public gardens. They are also considered as raw materials for some medicinal and industrial purposes.

Cactus plants Aeonium canariense L. (Webb \& Berthelot) belong to the genus Aeonium which Aeonium is of about 35 species of succulent, subtropical plants of the family Crassulaceae. Most of them are native to the Canary Islands. Some species are found in the tropical and subtropical regions, e.g. Madeira, Morocco and eastern Africa in Ethiopia [1,2].

The knowledge about diseases affecting this plant is somewhat limited. The available literature revealed that some attention was paid to cactus plants in the last few decades. However, some serious diseases were reported on cactus in certain report to cause ashy stem rot (charcoal rot) caused by Macrophomina phaseolina which considered as one of fungal diseases infected cacti plants [3] as well as medicinal coleus (Coleus forskohlii) which firstly reported by Kamalakannan et al. [4].

Ashy stem blight or Charcoal rot, caused by Macrophomina phaseolina (Tassi) Goid, is favored by warm dry growing conditions and is often associated with drought stress although charcoal rot disease has been found under humid tropical conditions. Macrophomina phaseolina can infect a broad array of major crops including common bean, maize, sorghum, soybean, sesame and cotton $[5,6]$. The common name of the disease caused by $M$. phaseolina derives from the symptoms present on adult plants where stem tissues show the growth of numerous microsclerotia and pycnidia. Ashy stem blight exhibits significant morphological, physiological, pathogenic and genetic variability which makes the pathogen more capable of adapting and attacking susceptible hosts in diverse environments. Diversity in $M$. phaseolina is due to the heterokaryotic condition of mycelium as well as the presence of two asexual sub-phases, one saprophytic ( $R$. bataticola) where microsclerotia and mycelia are mainly produced and another pathogenic $[7,8]$ where microsclerotia, mycelia and pycnidia are produced in host tissues.

Macrophomina phaseolina (Tassi) Goid is an important phytopathogen distributed worldwide and causes charcoal rot on more than 500 plant species $[9,10]$. Moreover, this fungus survives in soil by multicellular jet black microsclerotia produced enormously during parasitic phase and/or saprophytic phase [11]. Sclerotia of $M$. phaseolina are such a potent resting body that each and every cell is potential to germinate and cause disease.

The pathogen $M$. phaseolina generally affects the fibrovascular system of the roots and basal internodes, impends the transport of nutrients and water to the upper parts of the plant. Progressive wilting, premature dying, loss of vigor, and reduced yield are characteristic features of $M$. phaseolina infection [12].

Special emphasis has been given to the study of the charcoal rot disease due to its great capability to grow and attack crops grown under arid and water-stressed conditions. Cultural, chemical or biological strategies for disease management are not adequate to control the disease efficiently or economically. Genetic resistance appears promising for reducing damage and yield losses caused by the pathogen [13]. Research on this disease in ornamental plants is considered necessary in view of their wide economic use as indoor or outdoor decorations. Currently, the management of root rot diseases is possible only through the use of a combination of control

*Corresponding author: Mokhtar M. Abdel-Kader, Department of Plant Pathology National Research Centre, Dokki, 12622, Giza, Egypt; E-mail: mokh nrc@yahoo. $\underline{\mathrm{com}}$

Accepted November 25, 2010; Published November 29, 2010

Citation: Abdel-Kader MM, El-Mougy NS, Aly MDEH, Lashin SM (2010) First Report of Ashy stem blight caused by Macrophomina phaseolina on Aeonium canariense in Egypt. J Plant Pathol Microbiol 1:101. doi:10.4172/2157-7471.1000101

Copyright: (c) 2010 Abdel-Kader MM, et al. This is an open-access article distributed under the terms of the Creative Commons Attribution License, which permits unrestricted use, distribution, and reproduction in any medium, provided the original author and source are credited. 
options (cultural, chemical and biological) which utilize the concept of Integrated Pest Management (IPM). Chemical control is the main strategy for root rot diseases management in many countries all over the world. Gabr et al. [14] found that Benlate was very effective in decreasing infection by $M$. phaseolina when applied at $0.5 \mathrm{~g} / \mathrm{hill}$ under field conditions. Moreover, Singh and Kumar [15] reported that seed treatment with Topsin M $(1.0 \mathrm{~g} / \mathrm{kg}$. seed), bavistin $50 \mathrm{WP}$, indofil M-45 and jkstein (each $2.0 \mathrm{~g} / \mathrm{kg}$. seed) eliminated the fungus M. phaseolina from the infected urdbean seeds.

On the other hand, biological agents could be an important component in the control of $M$. phaseolina if effective and reliable formulations are readily available, and could be integrated with chemical fungicides. The antagonistic activity of Trichoderma species against plant pathogens has been studied extensively [16,17]. In this regard, $T$. harzianum has been evaluated for the control of charcoal stem and root rot of melon $[18,19]$.

It is interesting to note here that Macrophomina phaseolina affects the cactus Aeonium canariense, as one of the decorative plants. Therefore, the present study was planned to identify the causal pathogen and to study sensitivity of the pathogen to temperatures as well as the effectiveness of the fungicide Topsin-M and the bioagent Trichoderma harzianum individually or integrated under laboratory and nursery conditions for controlling the disease.

\section{Materials and Methods}

\section{Isolation, identification of the causal pathogen}

Samples of cactus Aeonium canariense, showing ashy stem blight symptoms, were collected from some private nurseries of ornamental plants production. Isolation of the pathogens was carried out from infected plant tissue showing disease characteristics and bearing fungal sclerotia were selected. The tissue was cut into $5 \mathrm{~mm}$ long and $2-3 \mathrm{~mm}$ thick pieces. These pieces were surface sterilized with $1 \% \mathrm{NaOCl}$ solution for about 2 minutes followed by thorough washing with sterilized water, then air dried between folded of sterilized filter papers. These surface sterilized pieces were transferred to Potato Dextrose Agar (PDA) medium (Difco Laboratories, Detroit, MI) in $9 \mathrm{~cm}$ diameter Petri plates. The plates were incubated in dark at $30 \pm 2^{\circ} \mathrm{C}$ for up to five days. Hyphal tips of the grown fungus were taken from the developing colonies appeared from plant tissues and transferred to slant of PDA. The fungus was identified according to cultural and microscopical characters described by Barnett and Hunter [20] and Wheeler [21]. The fungal pure culture was maintained in refrigerator at $4^{\circ} \mathrm{C}$, then maintained for further studies.

\section{Pathogen and antagonist}

The isolated pathogenic fungus $M$. phaseolina in addition to one isolates of the antagonistic microorganism T. harzianum $\left(\mathrm{T}_{\mathrm{M} 13}\right)$ obtained from Culture Collection Centre of the Plant Pathology Department of the National Research Centre, Giza, Egypt. The antagonistic microorganism was isolated from the rhizosphere of various healthy and root rot infected leguminous and field crops, grown in the Delta and Middle Egypt regions, and proved its high antagonistic ability during previous work at the same department. Fungal cultures were maintained on potato dextrose agar (PDA) slant media at $4^{\circ} \mathrm{C}$ as stock cultures until use. All isolates were refreshed by growing at the optimum growth conditions (at $30 \pm 1^{\circ} \mathrm{C}$ for five days on $12 \mathrm{hr}$ alternative light and dark conditions) at the beginning of the present experiments.

\section{Sensitivity test against temperature}

Effect of temperature on the linear growth was studied in vitro. Plates containing PDA medium were inoculated with $5 \mathrm{~mm}$ discs of the fungal growth taken from the edge of 10-day-old cultures grown on the same medium. These plates were incubated at different temperatures, i.e. $10,15,20,25,30,35,40$ and $45^{\circ} \mathrm{C}$. Five plates were used as replicates for each temperature treatment. The average diameter of the fungal colonies was measured after 7 days from incubation.

\section{Sensitivity test against fungicides}

The inhibitory effect of the fungicide Topsin-M 70WP on the linear growth of either the pathogen $M$. phaseolina or the bioagent T. harzianum was evaluated in vitro. Different concentrations, i.e. 0.5, 1.0, 2.0, 3.0, 4.0, 5.0, 6.0, 7.0, 8.0, 9.0 and 10ppm, based on the active ingredient of Topsin-M (a.i. 70\%), were added to autoclaved PDA medium before pouring in Petri dishes. Control treatment was fungicide-free medium. A disk 5-mm-disk of 10-day-old of each fungal growth was placed individually in the centre of Petri dishes. All plates were incubated at $30 \pm 1^{\circ} \mathrm{C}$ and examined after 7 days when the full growth of tested fungi was observed in control treatment. This test was repeated three times and the percentage of reduction in fungal growth was calculated in relative to control treatment. Five replicates were used for each particular treatment as well as control.

Furthermore the effect of the fungicide on the efficacy of antagonistic ability of $T$. harzianum against the pathogen $M$. phaseolina was also evaluated using the modified dual culture technique [22]. In vitro antagonistic studies of bioagent microorganism and pathogenic fungus were performed on PDA medium in 9-cm-diameter Petri dishes supplemented with the same different fungicidal concentrations tested as mentioned above. A 5-mm disk of the antagonistic growth culture was placed onto the PDA, $10 \mathrm{~mm}$ from the edge of the Petri dish. Another disk of the same diameter of the pathogenic fungal growth culture was placed on the opposite side of the dish at the same distance. This procedures were done for each of the same above mentioned fungicidal concentration tested. The control treatment was inoculated with a culture disk of either a pathogenic or antagonistic culture alone at the same conditions. Both experimental and control dishes were assigned to a completely randomized design, with five replicates per treatment. All inoculated Petri dishes were incubated at $28 \pm 1^{\circ} \mathrm{C}$ and the fungal growth diameter away from and towards the antagonist agent was measured after the pathogenic fungal growth in the control treatment had reached the edge of the Petri dish. This test was repeated three times and the inhibition was calculated as the percentage reduction in colony diameter growth compared with the control.

\section{Disease control}

Fungicidal as well as biological control application as protective treatment measures were carried out under the open natural conditions of the main nursery garden of National Research Centre, Giza, Egypt during July-August 2010. The summer hot whether in Egypt in this period of the year is humid (70-75\%) and the day and night temperatures were $38-25^{\circ} \mathrm{C}$. Evaluation of the fungicide Topsin-M and the bioagent $T$. harzianum individually or integrated against ashy stem blight incidence caused by $M$. phaseolina was performed in pot experiments. Experiment was carried out in a sandy loam soil artificially infested with the pathogen $M$. phaseolina. Fungal mass production used for soil infestation was obtained by growing the tested fungi (M. phaseolina or T. harzianum) on sand barley medium. This natural medium was prepared by mixing sand and barley $(1: 1$, 
$\mathrm{w}: \mathrm{w}$ and $40 \%$ water), then the mixture was packed into glass bottles sealed with cotton plugs and sterilized for three successive periods at $121^{\circ} \mathrm{C}$. The autoclaved medium was then inoculated individually with a 5 - $\mathrm{mm}$ disk of each fungal growth and incubated at $28 \pm 1^{\circ} \mathrm{C}$ for 2 weeks. Soils were infested individually at a ratio of $5 \%(\mathrm{w}: \mathrm{w})$ with pathogenic fungal cultures and mixed thoroughly to ensure equal distribution of fungal inoculum, then divided into two groups. The first group was left to contains only infested soil with the pathogen, while the second group was artificially infested with the antagonistic bioagent culture at the same ratio of $5 \%(\mathrm{w}: \mathrm{w})$ and mixed thoroughly to ensure equal distribution of fungal inoculum. All infested soils (the two groups) were filled in plastic pots (25-cm-diameter) in relation to soil infestation treatment and irrigated every second day for 1 week, then juveniles of cactus Aeonium canariense L. seedlings were transplanted at the rate of one seedling per pot. The applied treatments were designed to be as follows:

- Soil infested with the pathogen only and considered as comparison control treatment.

- Soil infested with the pathogen only and treated with the fungicide Topsin-M as chemical control treatment.

- Soil infested with the pathogen and the bioagent as biological control treatment.

- Soil infested with the pathogen and the fungicide Topsin-M as integrated control treatment.

The fungicidal treatment Topsin- $\mathrm{M}$ was applied as plants irrigation each five days at the rate of $500 \mathrm{mg} / \mathrm{L}$ water.

Fifteen cactus juveniles (pots) were used as replicates for each particular treatment. All treatments were assigned to a completely randomized design and irrigated every five days. Observations for the appearance of ashy stem blight disease symptoms were recorded throughout the experiment period which extended up to one month from the beginning of application time. The reduction in disease incidence at various treatments relatively to control was calculated.

\section{Statistical analysis}

One way analysis of variance (ANOVA) was used to analyze differences between fungal growth and incubation temperatures as well as toxicity of the fungicide Topsin- $\mathrm{M}$ at different concentrations and the growth reduction of tested fungi and antagonistic ability of the bioagent tested against the pathogen in vitro. General Linear Model option of the Analysis System SAS [23] was used to perform the analysis of variance. Duncan's Multiple Range Test was used for means separation [2wq24].

\section{Results and Discussion}

\section{Identification of the isolated fungus}

Cactus plants Aeonium canariense showing ashy stem blight

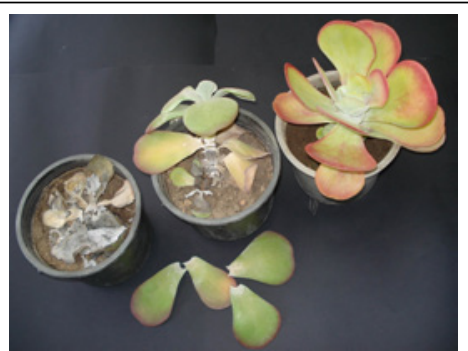

Plate 1: Ashy stem blight disease symptoms on cactus Aeonium canariense L. whereas healthy (right); diseased (middle) and dead plant (left).

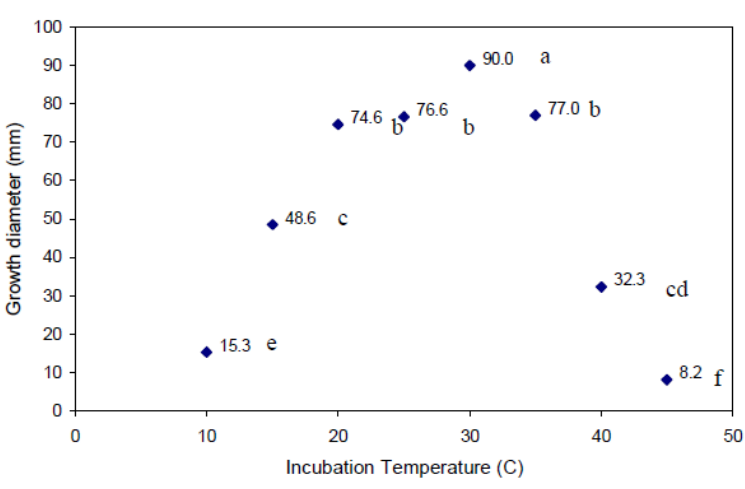

*Mean values followed by the same letter are not significantly defferent $(P \leq 0.05)$ Figure 1: Effect of temperature on the linear growth of $M$. phaseolina in vitro.

symptoms were observed at the main garden of the National Research Centre, Giza, Egypt as well as some private nurseries of ornamental plants production. Disease symptoms on stalks appear as silver-gray lesions near the base, which eventually decay the stem and tap root, leaving a shredded appearance. Stems become hollow, rotted, and may lodge easily [Plate 1]. Numerous tiny black fungus bodies called sclerotia are formed on the decayed tissues giving the stalks a charred appearance. The cause of ashy stem blight disease, Macrophomina phaseolina (Tassi) Goid was isolated from bases of affected cactus plants. All the obtained isolates were identified and have been similar according to Barnett \& Hunter, [20] and Wheeler [21]. The Taxonomic Description of Macrophomin phaseolina [21] was as follows: Division Eumycota; Sub Division Deuteromycotina; Class Coelomycetes; Order Sphaeropsidales; Family Sphaeropsidaceae; Genus Macrophomina; Species phaseolina. In this regard, similar disease symptoms of ashy stem blight (charcoal rot) caused by Macrophomina phaseolina (Tassi) Goid on various plants including common bean, maize, sorghum, soybean, sesame and cotton were recorded $[5,6,9,25,10]$. These records lead to thought that the present study is the first report that Macrophomina phaseolina (Tassi) Goid could cause ashy stem blight (charcoal rot) infection to decorative cactus plants Aeonium canariense.

\section{Sensitivity test against temperature}

The effect of different temperatures on linear growth of $M$. phaseolina was studied in vitro. Obtained results in Figure 1 show that fungal growth significantly affected with the tested temperature degrees. The fungal growth was increased in parallel with the increasing of incubation temperatures to reach its optimum, $90 \mathrm{~mm}$, growth at $30^{\circ} \mathrm{C}$, then the growth dramatically decreased above this temperature point. Minimum fungal growth, $8.2 \mathrm{~mm}$, was observed at $45^{\circ} \mathrm{C}$. Similar results are in a harmony with the present records.

Cultural temperature optima between 30 and $37^{\circ} \mathrm{C}$ are common for $\mathrm{M}$. phaseolina isolates, and microsclerotia of the pathogen have been reported to survive soil temperatures in excess of $55^{\circ} \mathrm{C}[26,27]$. Moreover, Mihail and Alcorn [28] have reported the thermal death range of the test fungus between $50-55^{\circ} \mathrm{C}$. However, it can tolerate temperature up to $50-52^{\circ} \mathrm{C}$ for about $120 \mathrm{~h}[29]$. Beyond $50^{\circ} \mathrm{C}$ the fungal sclerotia become inactivated within $24 \mathrm{~h}$, but they are not killed [30]. So it is possible for M. phaseolina to tolerate this temperature range even after a slight inactivation of some of sclerotial cells by thermal killing, because all the cells of a sclerotium function as independent unit [31]. These reports could explain that the rootrot caused by Macrophomina remains to be a challenging task in 
terms of management, since it is soilborne in nature. It is distributed worldwide and is prevalent in arid, subtropical and tropical climate, especially in the areas with low rainfall and high temperature [32,33].

\section{Sensitivity test against fungicides}

Various disease management methods have been implemented to combat and eradicate pathogenic fungi. These include cultural, regulatory, physical, chemical biological methods. All these methods are effective only when employed well in advance as precautionary measure $[34,35]$. Once a disease has appeared, these methods become impractical / ineffective. In that situation, chemical control offers a good choice to grower to control the disease. Chemical pesticides have been in use since long and they provide quick, effective and economic management of plant diseases. The present study conducted with evaluating the inhibitory effect of the fungicide Topsin-M on the fungal growth in vitro. Data in Table 1 show the inhibitory effect of different concentrations of Topsin-M on the growth of either $M$. phaseolina and $T$. harzianum as well as their influence on the antagonistic ability of the bioagent $T$. harzianum against the pathogen $M$. phaseolina. Presented data revealed that the growth of both fungi reduced gradually by increasing the fungicide concentrations. Complete growth inhibition of $M$. phaseolina was observed at concentration of $4 \mathrm{ppm}$, while the growth of $T$. harzianum completely inhibited at concentration of $10 \mathrm{ppm}$. In this regard, almost similar effect of different fungicides against the growth of $M$. phaseolina were reported. Since no registered fungicide is available against $M$. phaseolina [36], this preliminary study would be helpful to suggest the fungicide Topisn-M for the management of the fungus M. phaseolina. Dubey and Kumar [37] found that azadirachtin, mancozeb and bavistin had announced effect on growth and sclerotial survival of $M$. phaseolina in vitro. The soilborne diseases affecting sesame plants, including charcoal rot (Macrophomina phaseolina), could be controlled by fungicidal treatments. El-Khadem et al. [38] stated that, Benlate as seed dressing was the most effective against artificial infection of sesame root rot and wilt diseases and produced the highest survival plants. The combined soil and seed treatment (Ronilan + Benlate) was the best for minimizing root rot and wilt diseases under field conditions followed by Ronilan + Thiram, Homai + Thiram and Vitavax-T + Thiram. Khalifa [39] reported that Benlate and Rizolex-T were the best for controlling M. phaseolina and Fusarium oxysporum infections and increasing healthy mature plants of sesame in greenhouse. The combined seed and soil treatments of Rizolex-T + chloroyhecieb or Benlate + chloroyhecieb were superior for controlling root rot and wilt diseases and increased seed yield of sesame under field conditions. In pot experiments, Gabr et al. [14] found that Benlate and Rizolex-T as soil treatments decreased the incidence of wilt and root rot diseases of sesame plants. Benlate was very effective in decreasing infection by $M$. phaseolina and $F$. oxysporum when applied at $0.5 \mathrm{~g} / \mathrm{hill}$ under field conditions. Moreover, El-Fiki et al. [40] reported that applying the fungicides Benlate, Rizolex-T, Amconil and Vitavax-T individually or in combination as seed treatments were significantly effective in reducing charcoal rot disease incidence and increasing sesame seed yield production under greenhouse and field conditions.

On the other hand data in Table 1 also show that the antagonistic ability of the bioagent $T$. harzianum affected with the presence of the fungicide in the growth medium. Trichoderma harzianum inhibited mycelial growth of $M$. phaseolina in a dual culture free of fungicide by $33.3 \%$. Mycelial growth of the pathogen was drastically reduced by 53.6 and $82.2 \%$ at the fungicidal concentrations of 0.5 and $1.0 \mathrm{ppm}$, respectively. Complete inhibition of $M$. phaseolina was observed at concentration of 2ppm. In this concern, Etebarian [19] reported that cell-free metabolites of T. harzianum (M), T. harzianum (T39) and $T$. virens (DAR 74290) inhibited growth of $M$. phaseolina completely in vitro and appeared to be fungicidal. Ramezani [41] evaluated the efficacy of four fungal bioagents viz., Trichoderma hamatum, $T$. harzianum $T$. polysporum and $T$. viride in vitro condition against the Eggplant root - rot pathogen, Macrophomina phaseolina. Among the bioagents, $T$. harzianum produced the maximum inhibition zone of $18.20 \%$ compared to the minimum of $7.30 \%$ by $T$. hamatum. However, in recent past, it has been realized that use of chemical in agriculture is not as beneficial as it was visualized. Chemical pose serious and health hazards to an applicator as well as to a consumer of the treated material. In addition to target organism, pesticides also kill various beneficial organisms. Their toxic forms persist in soil and contaminate the whole environment [42]. Increasing awareness of humankind toward the ecosystem and environment has made a marked shift from synthetic materials to bio-products. Fungi constitute a major group of bioagents against various kinds of pests. A good number of fungi such as Trichoderma, Gliocladium can suppress the parasitism of Fusarium sp., Rhizoctonia sp., Sclerotium sp. [43,44].

\section{Disease control}

Disease management strategies primarily depend on sanitary practices and well timed fungicide applications. However development of fungicide resistance within population of $M$. phaseolina became a problem and alternative approaches that can be incorporated into integrated pest management of charcoal rot disease are needed [19]. Biological control is coming up as an alternative strategy for disease management, which is also ecology-conscious and environment friendly. Several fungal (Trichoderma sp.) and bacterial (Pseudomonas

\begin{tabular}{|c|c|c|c|c|c|c|}
\hline \multirow{2}{*}{ Topsin-M concentrations (ppm) } & \multicolumn{2}{|l|}{ M. phaseolina } & \multicolumn{2}{|l|}{ T. harzianum } & \multicolumn{2}{|l|}{ Antagonistic ability ${ }^{\star *}$} \\
\hline & linear growth $(\mathrm{mm})$ & Reduction \% & linear growth $(\mathrm{mm})$ & Reduction \% & linear growth $(\mathrm{mm})$ & Reduction \% \\
\hline 0 & $90 a^{*}$ & - & 90 & - & $60 \mathrm{bc}$ & 33.3 \\
\hline 0.5 & $68 \mathrm{~b}$ & 24.4 & 90 & 0.0 & $42 \mathrm{de}$ & 53.6 \\
\hline 1 & $52 \mathrm{c}$ & 42.2 & 87 & 3.3 & $16 \mathrm{~g}$ & 82.2 \\
\hline 2 & $26 \mathrm{f}$ & 71.1 & 77 & 14.4 & $0 \mathrm{i}$ & 100 \\
\hline 3 & $12 \mathrm{~g}$ & 86.7 & 60 & 33.3 & $0 \mathrm{i}$ & 100 \\
\hline 4 & $0 \mathrm{i}$ & 100 & 52 & 42.2 & $0 \mathrm{i}$ & 100 \\
\hline 5 & $0 \mathrm{i}$ & 100 & 40 & 55.6 & $0 \mathrm{i}$ & 100 \\
\hline 6 & $0 \mathrm{i}$ & 100 & 34 & 62.2 & $0 \mathrm{i}$ & 100 \\
\hline 7 & $0 \mathrm{i}$ & 100 & 26 & 71.1 & $0 \mathrm{i}$ & 100 \\
\hline 8 & $0 \mathrm{i}$ & 100 & 18 & 80.0 & $0 \mathrm{i}$ & 100 \\
\hline 9 & $0 \mathrm{i}$ & 100 & 8 & 91.1 & $0 \mathrm{i}$ & 100 \\
\hline 10 & $0 \mathrm{i}$ & 100 & 0 & 100 & $0 \mathrm{i}$ & 100 \\
\hline
\end{tabular}

*Mean values within columns followed by the same letter are not significantly different $(P \leq 0.05)$

*Antagonistic ability of $T$. harzianum against $M$. phaseolina [Reduction in growth of pathogenic fungus was calculated relatively to the growth in control treatment $(60 \mathrm{~mm})]$

Table 1: Effect of different concentrations of Topsin-M on the linear growth ( $\mathrm{mm}$ ) of $M$. phaseolina and T. harzianum and their influence on the antagonistic ability of the bioagent against the pathogenic fungus in vitro. 


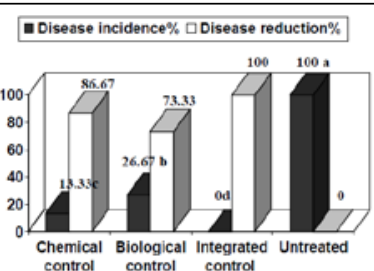

Figure 2: Effect of chemical and biological individually or integrated on ashy stem blight disease incidence of cactus seedlings $A$. canariense caused by $M$. phaseolina under greenhouse conditions.

sp. and Bacillus sp.) antagonists, have been successfully used as biocontrol agents in the control of seed and soil borne pathogens like Sclerotium rolfsii, Rhizoctonia solani, Fusarium oxysporum and Sclerotinia sclerotiorum in the various crops $[45,46,47,48,49]$. Application of Trichoderma viride, Pseudomonas and Bacillus sp. have been found to substantially control seedling, root rots and stalk rots of maize caused by Fusarium graminearum, when used as seed inoculant $[50,51]$.

Incidence of charcoal rot was substantially reduced after seed treatment of mungbean and sunflower by Trichoderma harzianum, Gliocladium virens and Streptomyces sp. [52]. Most of the time, fungicides produce undesirable effects on non-targeting organisms, so the use of microorganisms that antagonize plant pathogenic fungi is risk free [53]. Moreover, the combination of fungicide tolerant biological control agents with reduced levels of fungicide integrated control strategies would promote the degree of disease suppression similar to that achieved with full dosage of fungicides [54]. There are reports where the biocontrol agents, which can tolerate fungicides up to a certain level, were mixed with fungicides and resulted in eradication of diseases [55].

In the present study, presented data in Figure 2 show that under greenhouse conditions application of integrated treatment of $T$. harzianum and Topsin-M had superior effect for suppressing the disease incidence of cactus plants Aeonium canariense L. by $100 \%$ comparing with each individual treatment of either fungicide (86.67\%) or the bioagent $(73.33 \%)$. Similar results are recorded by several investigators. Khalifa and Linddel [18] reported that $T$. harzianum has been evaluated for the control of charcoal stem and root rot of melon in Egypt. Also, T. viride (MO) inhibited fungal growth from $34.9 \%$ to $71 \%$. T. harzianum (T39), T. harzianum (M), T. virens (DAR 74290), $T$. viride (MO) and T. harzianum (Bi) were tested for their ability to protect melon plants from charcoal stem rot disease caused by $M$. phaseolina in a glasshouse experiment [19]. Moreover, Latore et al. [56] suggested that antagonistic activity of biocontrol agents might be effective if it is integrated with other control practice and may result in acceptable levels of disease control with reduce level of chemicals use. Latore et al. [56] suggested that antagonistic activity of biocontrol agents might be effective if it is integrated with other control practice and may result in acceptable levels of disease control with reduce level of chemicals use. In the present study as for disease control under greenhouse conditions it was found that the ashy stem blight disease incidence of cactus Aeonium canariense L. was suppressed when either the bioagent $T$. harzianum and/or Topsin-M applied as biological, chemical and integrated control. It could be conclude that application of such treatments might be used as successful control measure for the ashy stem blight disease. Moreover, these suggestions could be a helpful guide for cactus plants growers in commercial nurseries.

\section{References}

1. Anonymous 2010a. Aeonium (Genus). http://zipcodezoo.com/Key/Plantae/ Aeonium_Genus.asp

2. Anonymous 2010b. Aeonium. http://en.wikipedia.org/wiki/Aeonium

3. Anonymous, 2003. Fungal Infections of Cacti. http://www.centralarizonacactus org/plantinfo/pests/FUNGAL\%20INFECTIONS\%200F\%20CACTI.pdf

4. Kamalakannan A, Mohan L, Valluvaparidasan V, Mareeswari P, Karuppiah R (2005) First report of Macrophomina root rot (Macrophomina phaseolina) on medicinal coleus (Coleus forskohlii) in India. New Disease Reports 55: 302.

5. Mayek-Perez N, Lopez-Chestnut G, Lopez-Salt mines C, Cumpián-Gutiérrez E, Acosta-Gallegos JA (2001) Resistance to Macrophomina phaseolina in common kidney bean under field conditions in Mexico. Agrociencia 35: 649661.

6. Mayek-Perez N, Lopez-Chestnut grove C, Acosta-Gallegos JA (2002) Reaction of germ plasm of Phaseolus sp. against Macrophomina phaseolina. Mexican Fitotecnia magazine 25: 35- 42.

7. Beas-Fernandez RA, De Santiago-De Santiago, Hernandez-Delgado S, Mayek-Perez N (2006) Characterization of Mexican and non-Mexican isolates of Macrophomina phaseolina based on morphological characteristics, pathogenicity on bean seeds and endoglucanase genes. Journal of Plant Pathology 88: 53-60.

8. Reyes-Franco, M.C., S. Hernández-Delgado, R. Beas-Fernández, M. MedinaFernández, J. Simpson, N. Mayek-Pérez. 2006. Pathogenic and Genetic variability within Macrophomina phaseolina from Mexico and other countries. Journal of Phytopathology 154: 447-453.

9. Wyllie TD, 1988. Charcoal rot of soybean-current status. In Soybean diseases of the north central region. Wyllie TD. and Scott DH. (eds.) APS Press, St. Paul, MN.

10. Das IK, Fakrudin B, Arora DK, (2008) RAPD cluster analysis and chlorate sensitivity of some Indian isolates of Macrophomina phaseolina from sorghum and their relationships with pathogenicity. Microbiol Res 163: 215-224.

11. Dubey RC, Upadhyaya RS (2001) Survival and control of Macrophomina phaseolina (Tassi) Goid. In: "Innovative Approaches in Microbiology" (eds. D.K. Maheshwari and R.C. Dubey). Bishan Singh Mahendrapal Singh, Dehradun, India., pp 169-190.

12. Kaisar SAKM, Das SN (1988) Physical factors that influence the growth and spread of charcoal rot pathogen (Macrophomina phaseolina) infecting maize. J. Phytopathol 123: 47-51.

13. Aboshosha SS, Attaalla SI, El-Korany AE, El-Argawy E (2007) Characterization of Macrophomina phaseolina isolates affecting sunflower growth in El-Behera governorate, Egypt. Int J Agric Biol 9: 807-815

14. Gabr MR, Hussein NA, Saleh OI, Khalil MA (1998) Susceptibility of certain varieties and genotypes and control of wilt and root rot diseases of sesame attributed to Fusarium oxysporum f.sp. sesami and Macrophomina phaseoli. Egypt J Microbiol 33: 403-428.

15. Singh J, Kumar K (2002) Location, Survival, Transmission and Control of Seedborne, Macrophomina phaseolina Causing Dry Root Rot and Leaf Blight in Urdbean. Annals of Plant Protection Sciences 10: 0971-3573.

16. Krause MS, Madden LV, Hortink AJ (2001) Effect of Potting Mix Microbial Carrying Capacity on Biological Control of Rhizoctonia Damping-off of Radish and Rhizoctonia Crown and Root Rot of Poinsettia. Phytopathology 91: 11161123.

17. Buns JR, Benson DM (2000) Biocontrol of Damping-off of Catharanthus roseus Caused by Pythium ultimum with Trichoderma virens and Binucleate Rhizoctonia fungi. Plant Dis 48: 644-648.

18. Khalifa EZ, Lindell CM (1995) Biological Management of Macrophomina phaseoli. Plant Protection Congress The Hague Netherlands 521.

19. Etebarian HR (2006) Evaluation of Trichoderma Isolates for Biological Contro of Charcoal Stem Rot in Melon Caused by Macrophomina phaseolina. J. Agric. Sci. Technol 8: 243-250.

20. Barnett HL, Hunter BB (1972) Illusterated Genera of imperfect Fungi. Burgen Publ. Co., Minnesota. $241 \mathrm{pp}$

21. Wheeler H (1975) Plant pathogenesis. Academic Press New York and London $2-3$ 
Citation: Abdel-Kader MM, El-Mougy NS, Aly MDEH, Lashin SM (2010) First Report of Ashy stem blight caused by Macrophomina phaseolina on Aeonium canariense in Egypt. J Plant Pathol Microbiol 1:101. doi:10.4172/2157-7471.1000101

Page 6 of 6

22. Ferreira JHS, Matthee FN, Thomas AC (1991) Biological control of Eutypa lata on grapevine by an antagonistic strain of Bacillus subtilis. Phytopathology 81 : 283-287.

23. SAS Institute Inc 1996 SAS/STAT user's guide. 6: 846.

24. Winer BJ (1971) 'Statistical principles in experimental design.' 2: 596.

25. Khan SN (2007) Macrophomina phaseolina as causal agent for charcoal rot of sunflower. Mycopathology 5: 111-118.

26. Hodges CS (1962) Black root rot of pine seedlings. Phytopathology 52: 210 219 .

27. Dhingra,OD, Sinclair JB (1978) Biology and pathology of Macrophomina phaseolina. Imprensa Universitaria. Universidade Federal de Vicosa. Vicosa, Minas Gerais, Brazil. 166pp.

28. Mihail JD, Alcorn SM (1982) Effect of soil solarization on Macrophomina phaseolina and Scleortium rolfsii. Plant Disease 68: 156-159.

29. Paharia AK, Sahai D (1970) Effect of temperature on the viability of Macrophomina phaseoli from potato. Indian Journal of Microbiology 10: 107110.

30. Bega, RV, Smith RS (1962) Time-temperature relationships in thermal activation of sclerotia of Macrophomina phaseolina. Phytopathology 52: 632-635.

31. Wyllie TD, Brown MF (1970) Ultrastructural formation of sclerotia of Macrophomina phaseolina. Phytopathology 60: 524.

32. Tikhonov OI, Nedelko OK, Persestova TA (1976) Methods for pathogenicity tests for seed borne Macrophomina phaseolina isolated from different hosts. Phytopathology Z 88: 234-237.

33. Raut JG, Bhombe BB (1984) Longevity of M. phaseolina in sunflower seeds. Indian Phytopathology 37: 333-334.

34. Sharma PD (2000) Physical and cultural methods for the management of soil borne pathogens. Crop Protection 19: 725-731.

35. Kata J (2000) Physical and cultural methods for the management of soil borne pathogens. Crop Protection 19: 725-731.

36. Ashraf $\mathrm{H}$, Javaid A (2007) Evaluation of antifungal activity of Meliaceae family against Macrophomina phaseolina. Mycopathology 5: 81-84.

37. Dubey RC, Kumar R (2003) Efficacy of Azadirachtin and fungicides on growth and survival of sclerotia of Macrophomina phaseolina causing charcoal rot in soyabean. Indian Phytopathology 56: 216-217.

38. El-Khadem MM, Ali IN, Attalla SI, Barongy, Ebtihag SH (1991) Chemical and biological control of sesame root-rot and wilt diseases. Proc. 4th Conf. of Pests \& Dis. of Veg. \& Fruits in Egypt. Pp. 707-717

39. Khalifa MMA (1997) Studies of root-rot and wilt diseases of sesame plants M.Sc. Thesis, Fac. Agric., Moshtohor, Zagazig Univ., Benha Branch. 158pp.

40. El-Fiki All, El-Deeb AA, Mohamed FG, Khalifa MMA (2004) Controlling Sesame Charcoal Rot Incited by Macrophomina phaseolina under Field Conditions by using the Resistant Cultivars and some Seed and Soil Treatments. Egypt. J. Phytopathol 32: 103-118.

41. Ramezani H (2008) Biological Control of Root-Rot of Eggplant Caused by Macrophomina phaseolina. American-Eurasian J Agric \& Environ Sci 4: 218 220 .

42. Hayes WJ, Laws ER (1991) Handbook of Pesticide Toxicology. Academic Press Inc., New Delhi. Vol. 1

43. Rajappan K, Ramaraj B (1999) Evaluation of fungal and bacterial antagonists against Fusarium moniliforme causing wilt of cauliflower. Annals of Plant Protection Society 7: 205-207.

44. Lifshitz R, Windham MI, Baker R (1986) Mechanism of biological control of pre - emergence damping off of pea by seed treatment with Trichoderma species. Phytopathology 76: 720-725.

45. Kehri HK, Chandra S Antagonism of Trichoderma viride to Macrophomina phaseolina in the conrol of dry root rot of mung. Ind Phytopathol 44: 60-63.

46. Mukhopadhyay AN, Shrestha SM, Mukherjee PK (1992) Biological seed treatment for control of soil borne plant pathogens. FAO Plant Prot Bull 40 : $221-30$

47. Sankar P, Jeyarajan R (1996) Seed treatment for biological control of Macrophomina phaseolina in sesamum. Ind Phytopathol 49: 148-151.

48. Raguchander T, Rajappan K, Samiappan R (1997) Evaluating methods of application of biocontrol agents in the control of Mungbean root rot. Ind Phytopathol 50: 229-234.

49. Sharma SK, Verma BR, Sharma BK (1999) Biocontrol of Sclerotinia sclerotiorum causing stem rot of chickpea. Ind Phytopathol 52: 44-46.

50. Kommedahl T, Chang IP (1975) Biocontrol of corn root infection in the field by seed treatment with antagonists. Phytopathol 65: 296-300.

51. Chang IP, Kommedahl T (1968) Biological control of seedling blight of corn by coating kernels with antagonistic microorganisms. Phytopathology 58: 13951401.

52. Hussain S, Ghaffar A, Aslam M (1990) Biological control of Macrophomina phaseolina, charcoal rot of sunflower and mung bean. J. Phytopathol 130: 157160

53. Benítez T, Rincón AM, Limón MC, Codón AC (2004) Biocontrol mechanisms of Trichoderma strains. Int Microbiol 7: 249-260.

54. Monte E (2001) Understanding Trichoderma: between biotechnology and microbial ecology. Int Microbiol 4: 1-4.

55. De Cal A, Pascual S, Melgarejo P (1994) In vitro studies on the effects of fungicides on beneficial fungi of peach twig mycoflora. Mycopathologia 126 15-20.

56. Latore BA, Agosin E, San Martin R, Vasquez GS (1997) Effectiveness of conidia of Trichoderma harzianum produced by liquid fermentation against Botrytis bunch rot of table grape in Chile. Crop Protection 16: 209-214. 